\title{
SZÁMÍTÓGÉPES DOHÁNYZÁS-PREVENCIÓ AZ ISKOLÁBAN
}

Szerzők:

Csibi Mónika (PhD)

Marosvásárhelyi Orvosi

és Gyógyszerészeti Egyetem

(Románia)

Csibi Sándor (PhD)

Marosvásárhelyi Orvosi

és Gyógyszerészeti Egyetem

(Románia)

Első szerző e-mail címe:

csibi.sandor@umftgm.ro

\section{Lektorok:}

Kelemen Lajos (PhD)

Okoskocka Kft.
Szabóné Balogh Ágota (PhD)

Gál Ferenc Főiskola

\begin{abstract}
Absztrakt
Prospektív kutatásunk egy számítógépes prevenciós beavatkozás elvégzése után jelentkező dohányzási motiváció-átstrukturálódásokat elemzi. A résztvevőinket 16 marosvásárhelyi középiskola tanulóiból választottuk ki, összesen 1369, 15-16 év közötti serdülőt. Eredményeink szerint a dohányzó serdülők magasabb dohányzás melletti motiváció értékeket és kevesebb dohányzás elleni érveket mutatnak a nem dohányzó serdülőkkel szemben. A programban való részvétel eredményeként a dohányzó serdülők cigarettafogyasztása jelentősen csökken, így arra következtetünk, hogy a számítógépes prevenciós program sikeresen alkalmazható serdülő populáción.
\end{abstract}

Kulcsszavak: dohányzás, prevenció, számítástechnika

Diszciplinák: pszichológia, informatika

\begin{abstract}
COMPUTER TOBACCO PREVENTION AT SCHOOL

Our prospective study analyzes the restructuring of smoking motivation after completing a computer-based prevention intervention. Our participants were selected from 16 high school students in Târgu Mureş, a total of 1369 adolescents aged 15-16. Our results show that smoking adolescents show higher motivation values for smoking and fewer arguments
\end{abstract}


compared to non-smoking adolescents. As a result of participating in the program, cigarette smoking among adolescent smokers is significantly reduced, thus we conclude that the computer-based prevention program can be successfully applied to the adolescent population.

Keywords: smoking, prevention, informatics

Disciplines: psychology, informatics

Csibi Mónika és Csibi Sándor (2019): Számítógépes dohányzás-prevenció az iskolában. Mesterséges intelligencia - interdiszciplináris folyóirat, I. évf. 2019/1. szám. 53-64.

doi: 10.35406/MI.2019.1.53

A WHO adatai szerint a dohányfüggôség a dohányfogyasztók felének halálát okozza, ez évente több, mint 7 millió embert jelent világszerte (WHO, 2017). A becslések szerint körülbelül 440 ezer amerikai hal meg évente a dohányzáshoz kapcsolódó betegségek miatt, közülük 90\% (396 ezer) serdülőkorban kezdett el dohányozni (CDC, 2014). Ez az oka annak, hogy a dohányzás napjaink egyik legelterjedtebb gyermek- és serdülőkori kockázati magatartásaként van számon tartva, annak ellenére, hogy befolyásolását számos ismertető, prevenciós vagy abbahagyást elősegítő iskolai program célozza. A 2017 felmérések eredményei szerint az Amerikai Egyesült Államokban a 12. osztályosok 9,7 százaléka, a 10. osztályosok 5,0 százaléka és a 8. osztályosok 1,9 százaléka használt cigarettát az elmúlt hónapban (Miech és mtsai., 2017). A gyermekek és serdülők a legveszélyeztetettebb korosztály a dohányzás elkezdése és kialakulása szempontjából (CDC, 2014). Előzetes ismeretek szerint a serdülők fejlődésbeli sajá- tosságaiból adódóan a nikotin hatással van az agy jutalmazási rendszerére és az érzelmi és kognitív funkciókban érintett agyterületekre (Smith és mtsai, 2015). Pénzes, Czeglédi, Balázs és Urbán (2017) követéses vizsgálatukban kimutatták, hogy a fiúk és a lányok hasonló arányban maradnak dohányzók, de a kutatásuk három éve alatt több lány szokott rá a cigarettára, mint fiú. Ugyanakkor, ebben a három éves időszakban a diákok 14,3\%-a szokott rá a cigarettára, de a leszokás aránya csak 3,3\% volt Pénzes, Czeglédi, Balázs és Urbán, 2017).

A serdülőkori dohányzási viselkedés megváltoztatásának folyamatát több pszichológiai elmélet és modell ismerteti. Közülük kutatásunk a T'TM modellhez igazodik leginkább, amely a viselkedésmódosítást egy dichotómiás folyamatként érzékelteti, ahol a változásra készséget mutató személyek eltérő attitűdökkel és meggyőződésekkel rendelkeznek, mint azok, akik még csak nem is gondolkodnak a változásokról (Brick és mtsai., 2017). A vál- 
tozásról szóló egyéni jellemzők lehetnek például a döntési egyensúly, az önhatékonyság, stb., amelyet az előnyök és hátrányok hozzáadott értékének mérésével mutatnak ki (Velicer és mtsai., 1985, Guo és mtsai., 2009). Így, azok a dohányzók, akik tudatában vannak a potenciálisan egészséget veszélyeztető magatartásuk jelenlétének és következményeinek, inkább motiváltak a dohányzási szokások abbahagyásában (Denford és mtsai., 2017). A kutatások az abbahagyási kísérletek indokaiként a jövőbeni egészséggel (73\%), a fizikai megjelenéssel (59\%), a cigaretta árával $(52 \%)$ és a sportteljesítménnyel (51\%) kapcsolatos aggodalmakat azonosították (Rinfel és mtsai., 2011). Pikó és Varga (2014) vizsgálatai rámutattak, hogy a serdülők gyakran az énmegerősítés és a coping (megküzdés) céljából kezdik el a szerfogyasztást.

Az egészségre káros viselkedések, és ezen belül a dohányzási magatartás megváltoztatásában a belső motiváció megváltoztatása elsődleges, amit orvosi közegben leginkább egy személyközpontú tanácsadási módszerrel, a „motivációs interjú” alkalmazásával lehet elérni (Lindson-Hawley, Thompson és Begh, 2015; Pócs, Hamvai és Kelemen, 2017). A belső motivációk megtalálása, valamint a kogníciók, meggyőződések mintázatának feltérképezése egyre fontosabbá válik a serdülőkori dohányzási magatartás visszaszorításának szempontjából. Így megerôsítést nyert, hogy az egyéni intervenciók mellett, a csoportos prevencióban szükség van olyan gyakorlati, dohányzókra fókuszáló kurzusokra is, ahol a dohányzásról való leszoktatás módszereinek alapjait is elsajátíthatják a dohányzók
(Pikó, 2008), de magát a leszoktatást leginkább speciális szakemberre bíznák (Rinfel és mtsai., 2011).

Kutatásunk célja, hogy a serdülők dohányzásra késztető motivációit felmérjük, valamint a dohányzás prevenciós és intervenciós programok elvégzése után jelentkező motiváció-átstrukturálódásokat elemezzük. Feltételezéseink szerint a nemdohányzó serdülők motivációit mélyítik, megerősítik a program nyújtotta információszolgáltatások, az esztétikai és szociális motivációk átadják helyüket a megküzdési és egészségi állapottal kapcsolatos motivációknak. A már dohányzó serdülőknél a program a pro smoking motivációk szignifikáns csökkenését, valamint a cons smoking motivációk jelentős növekedését eredményezik.

\section{Minta}

A romániai ASPIRA kutatásban eredetileg 16 marosvásárhelyi középiskola 79 kilencedik osztálya, szám szerint 2002 serdülő vett részt (Nădăşan és mtsai., 2016). A kutatás során több serdülő hiányzott az első vagy második tesztelés során, vagy a számítógépes prevenciós programot nem követte végig, ezért végül a végleges minta 1369, 15-16 év közötti serdülőből tevődött össze. A program hatékonyságának mutatójaként a módosított Fagerström Tolerancia Kérdőív alkalmazásával (mFTQ - modified Fagerström Tolerance Questionnaire), a dohányzó mintát két csoportra osztottuk, alacsony mFTK és magas mFTK értékkel jellemzett serdülők, attól függetlenül, hogy a kísérleti vagy a kontroll csoport tagjai voltak vagy nem (kis mérték- 
ben dohányzó és szenvedélyes dohányzó). Így a teljes minta 1275, (93,1\%) alacsony mFTK értékkel, és 94 (6,9\%), magas mFTK értékkel jellemzett serdülőből állt. Nem szerinti eloszlásuk arányos, a kísérleti csoportban 39 fiú és 53 lány, a kontrol csoportban pedig 584 fiú és 691 lány.

\section{Eszközök}

Az ASPIRA számítógépes dohányzás prevenciós és intervenciós program egy 88 itemes kérdőívcsomag kitöltésével kezdődött, amely demográfiai, pszichoszociális és dohányzási szokásokkal kapcsolatos adatokat szolgáltatott. Az Internetes felületen található kérdőívet a számítástechnikai laborban egy óra alatt, kutatási asszisztensek felügyelete alatt végezték el. A kérdőívek kitöltése után, több egyórás alkalommal a serdülők online általános és orvosi információkat kapnak a dohányzásról, a dohányzás következményeiről és korosztályukat célzó alternatív tevékenységekről. A program videókat, animációkat és interaktív tevékenységeket tartalmaz, a résztvevők képsorokat, kisfilmeket nézhetnek meg, orvosok, tanárok, valamint dohányzó serdülők beszámolóit hallgathatják meg A program célja, hogy információkat nyújtson, valamint a dohányzási attitűdök kognitív átstrukturálása által megelőzze a dohányzást, és leszokásra késztesse a már dohányzó serdülőket (Prokhorov és mtsai., 2010).

A dohányzás gyakoriságát az elmúlt 30 napban és naponta az elszívott cigaretták számával, valamint a dohányzási státusz változásait elemeztük, az alábbi kérdésekre adott válaszok segítségével: „Az elmúlt 30 napban bány napon cigarettárott?" (a válaszlehetőségek 0-egy napon sem, 1-egy-két napon, [...] és 6mindennap között helyezkednek el), „Kérjük, gondolja át azokat a napokat, az elmúlt 30 nap során, amikor cigarettázott. Hány cigarettát szivott el azokban a napokban?" (0-egyet sem, 1- kevesebb, mint egy cigarettát naponta, [...] és 6 több, mint 20 cigarettát naponta) és „Ar alábbi állitások közül melyik írja le a legjobban, bogy milyen gyakran cigarettárik??'(0-soha nem próbáltam ki, 1-egyszer megpróbáltam, de nem szívtam el végig, [...] és 11-több, mint egy csomaggal szívok el).

A kérdőívcsomag által tartalmazott, általunk felhasznált pszichológiai tesztek egyike a serdülőkre adaptált, módosított Fagerström Tolerancia Kérdőív (mFTQ, modified Fagerström Tolerance Questionnaire, Prokhorov és mtsai., 1998) amely a fizikai nikotinfüggés hét tünetét méri. Prokhorov és mtsai. (1998) javaslatai szerint, a hét mFTK item közül hatot négypontos skálával (0-3), a hetediket („A nap első két órájában többet dohányzol?’) bináris pontozással (igen $=1$, nem $=0$ ) használtuk. Mintánkban az mFTK kérdőív belső konzisztenciája az alapvizsgálatkor (Cronbach $\alpha=0,79)$ és utóvizsgálatkor (Cronbach $\alpha=0.69$ ) is jónak bizonyult.

A második alkalmazott kérdőív a 17 itemes Döntési Egyensúly Skála (DBS, Decisional Balance Scale, Plummer és mtsai., 2001), amely a dohányzási motivációkat vizsgálja. A skála dimenziói a dohányzás hátrányaira vonatkozó, egészségi (bealth cons) és esztétikai motivációkat (aesthetic cons), a dohányzást támogató előnyöket, megküzdést szolgáló érveket (coping pros) és a dohányzás melletti, tár- 
sas jellegú érveket (social pros) tartalmazza. A kérdőív itemei között szerepelnek, például „A dohányzás sárgára színezi a fogakat.” (esztétikai motiváció), „A dohányzó gyermekeknek több barátjuk van.” (társas motiváció) vagy „A cigarettázás oldja a feszültséget." (megküzdési motiváció). A válaszlehetőségek „1 - egyáltalán nem fontos” és „,5 - nagyon fontos” között helyezkednek el. A kérdőív megbízhatósága vizsgálatunkban nagyon jónak bizonyult (Cronbach $\alpha=0,80)$. Az etikai előírások vizsgálata után, az etikai engedélyt egy marosvásárhelyi egyetem kutatási bizottsága szolgáltatta.

Az adatok statisztikai feldolgozása az SPSS programcsalád (SPSS, Inc., Chicago, IL, USA) PASW csomagjának 18 verziójával történt. Az elemzések deskriptív statisztikai mu- tatókkal, kétváltozós t-teszttel, valamint az intervenciós csoportban Wilcoxon előjeles rangszám próba segítségével történtek.

\section{Eredmények}

A dohányzó serdülōk magasabb dohányzás melletti motiváció értékeket, valamint kevesebb dohányzás elleni érveket mutatnak a nem dohány ró serdülökekel szemben.

A teljes mintán, a dohányzási motivációk (DES) tekintetében, azok a serdülők, akiknek mFTK értékeik nagyobbak, magasabb Dohányzás melletti értékeket, de kisebb Dohányzás elleni értékeket mutatnak, ez a tendencia a Pro-Cons különbség értékeiben is fellelhető (1. táblázat).

1. táblázat: A dohányzási motivációk mintázata az mFTK értékele szerint, a kutatás kezdeti és végsö szakaszában, a teljes mintában (kétváltozós t teszt). Forrás: a Szerzőo

\begin{tabular}{|c|c|c|c|c|c|c|c|c|c|}
\hline \multirow[t]{2}{*}{ Változók } & \multirow[t]{2}{*}{ Kutatási szakasz } & \multicolumn{4}{|c|}{$\begin{array}{l}\text { Alacsony mFTK érték } \\
(\mathrm{N}=1275)\end{array}$} & \multicolumn{4}{|c|}{$\begin{array}{l}\text { Magas mFTK érték } \\
(\mathrm{N}=94)\end{array}$} \\
\hline & & Átlag & St.szórás & t-érték & $\mathrm{p}$ & Átlag & St.szórás & t-érték & $\mathrm{p}$ \\
\hline \multirow{2}{*}{ Social Pros } & Alapvizsgálat & 4.52 & 1.77 & \multirow{2}{*}{-1.21} & \multirow{2}{*}{0.22} & 5.71 & 2.56 & \multirow{2}{*}{0.50} & \multirow{2}{*}{0.61} \\
\hline & Utóvizsgálat & 4.59 & 1.91 & & & 5.58 & 2.56 & & \\
\hline \multirow{2}{*}{ Coping Pros } & Alapvizsgálat & 5.19 & 2.41 & \multirow{2}{*}{-1.18} & \multirow{2}{*}{0.23} & 8.07 & 3.18 & \multirow{2}{*}{1.81} & \multirow{2}{*}{0.07} \\
\hline & Utóvizsgálat & 5.28 & 2.50 & & & 7.55 & 2.90 & & \\
\hline \multirow{2}{*}{ Pros alskála } & Alapvizsgálat & 9.71 & 3.46 & \multirow{2}{*}{-1.44} & \multirow{2}{*}{0.14} & 13.78 & 4.62 & \multirow{2}{*}{1.55} & \multirow{2}{*}{0.12} \\
\hline & Utóvizsgálat & 9.87 & 3.84 & & & 13.13 & 4.66 & & \\
\hline \multirow{2}{*}{ Health Cons } & Alapvizsgálat & 12.87 & 2.86 & \multirow{2}{*}{9.49} & \multirow{2}{*}{$<0.01$} & 10.73 & 3.74 & \multirow{2}{*}{0.46} & \multirow{2}{*}{0.64} \\
\hline & Utóvizsgálat & 11.76 & 3.60 & & & 10.54 & 3.84 & & \\
\hline \multirow{2}{*}{ Aesthetic Cons } & Alapvizsgálat & 11.30 & 3.14 & \multirow{2}{*}{5.51} & \multirow{2}{*}{$<0.01$} & 8.85 & 3.61 & \multirow{2}{*}{-0.55} & \multirow{2}{*}{0.57} \\
\hline & Utóvizsgálat & 10.69 & 3.48 & & & 9.07 & 3.60 & & \\
\hline \multirow{2}{*}{ Cons alskála } & Alapvizsgálat & 24.12 & 5.52 & \multirow{2}{*}{8.15} & \multirow{2}{*}{$<0.01$} & 19.58 & 6.80 & \multirow{2}{*}{-0.04} & \multirow{2}{*}{0.96} \\
\hline & Utóvizsgálat & 22.46 & 6.67 & & & 19.61 & 6.79 & & \\
\hline \multirow{2}{*}{ Pro-Cons különbség } & Alapvizsgálat & -14.41 & 6.70 & \multirow{2}{*}{-7.97} & $<001$ & -5.79 & 9.42 & 078 & 043 \\
\hline & Utóvizsgálat & -12.58 & 7.97 & & $<0.01$ & -6.47 & 9.06 & 0.18 & 0.43 \\
\hline
\end{tabular}


$\mathrm{Ha}$ az adatokat az intervenciós-kontroll csoport szerint elemezzük, az eltérések egyre inkább kirajzolódnak, kiéleződnek. Ugyanakkor a kontroll csoportba tartozó, nem dohányzó serdülők a DES értékei nem mutatnak szignifikáns különbségeket a dohányzó fiataloknál, de a nem dohányzók esetében a Pros alskála értékei relatív stabilak, a Cons alskála értékei viszont jelentősen csökkennek. szerint nem mérvadó, a dohányzási érvek tekintetében nincs jelentős változás (2. táblázat). Az intervenció teljes mértékben eredményes az intervenciós csoportban, a dohányzó serdülők esetében, ahol a dohányzási motivációk dohányzás melletti értékei csökkennek (a Coping Pros jelentős mértékben), a Dohányzás elleni értékek pedig szignifikáns mértékben emelkednek, ami arra utal, hogy a

2. táblázat. A dohányzási motivációk mintázata az mFTK értékele squerint, a kutatás keqdeti és végsó szakaszában, az intervenciós csoportban (kétváltozós t tesz̨).

\begin{tabular}{|c|c|c|c|c|c|c|c|c|c|}
\hline \multirow[t]{2}{*}{ Változók } & \multirow[t]{2}{*}{ Kutatási szakasz } & \multicolumn{4}{|c|}{$\begin{array}{c}\text { Alacsony mFTK érték } \\
(\mathrm{N}=641)\end{array}$} & \multicolumn{4}{|c|}{$\begin{array}{c}\text { Magas mFTK érték } \\
(\mathrm{N}=34)\end{array}$} \\
\hline & & Átlag & St.szórás & t-érték & $\mathrm{p}$ & Átlag & St.szórás & t-érték & $\mathrm{p}$ \\
\hline \multirow{2}{*}{ Social Pros } & Alapvizsgálat & 4.45 & 1.83 & \multirow{2}{*}{-0.79} & \multirow{2}{*}{0.42} & 5.44 & 2.36 & \multirow{2}{*}{0.00} & \multirow{2}{*}{1.00} \\
\hline & Utóvizsgálat & 4.52 & 1.93 & & & 5.44 & 2.31 & & \\
\hline \multirow{2}{*}{ Coping Pros } & Alapvizsgálat & 5.19 & 2.49 & \multirow{2}{*}{-1.18} & \multirow{2}{*}{0.23} & 8.14 & 3.05 & \multirow{2}{*}{2.04} & \multirow{2}{*}{0.04} \\
\hline & Utóvizsgálat & 5.33 & 2.56 & & & 7.14 & 2.61 & & \\
\hline \multirow{2}{*}{ Pros alskála } & Alapvizsgálat & 9.64 & 3.62 & \multirow{2}{*}{-1.21} & \multirow{2}{*}{0.22} & 13.58 & 4.49 & \multirow{2}{*}{1.51} & \multirow{2}{*}{0.14} \\
\hline & Utóvizsgálat & 9.85 & 3.98 & & & 12.58 & 4.25 & & \\
\hline \multirow{2}{*}{ Health Cons } & Alapvizsgálat & 12.56 & 3.07 & \multirow{2}{*}{7.54} & \multirow{2}{*}{$<0.01$} & 10.85 & 3.79 & \multirow{2}{*}{-1.93} & \multirow{2}{*}{0.06} \\
\hline & Utóvizsgálat & 11.27 & 3.88 & & & 11.91 & 3.39 & & \\
\hline \multirow{2}{*}{ Aesthetic Cons } & Alapvizsgálat & 11.00 & 3.22 & \multirow{2}{*}{3.38} & \multirow{2}{*}{$<0.01$} & 9.17 & 3.64 & \multirow{2}{*}{-3.57} & \multirow{2}{*}{$<0.01$} \\
\hline & Utóvizsgálat & 10.45 & 3.66 & & & 10.94 & 3.61 & & \\
\hline \multirow{2}{*}{ Cons alskála } & Alapvizsgálat & 23.56 & 5.81 & \multirow{2}{*}{5.90} & \multirow{2}{*}{$<0.01$} & 20.02 & 6.78 & \multirow{2}{*}{3.31} & \multirow{2}{*}{$<0.01$} \\
\hline & Utóvizsgálat & 21.72 & 7.20 & & & 22.85 & 6.55 & & \\
\hline \multirow{2}{*}{$\begin{array}{l}\text { Pro-Cons } \\
\text { különbség }\end{array}$} & Alapvizsgálat & -13.91 & 6.98 & \multirow{2}{*}{-5.86} & $<001$ & -6.44 & 8.71 & 178 & $<001$ \\
\hline & Utóvizsgálat & -11.87 & 8.58 & & $<0.01$ & -10.26 & 8.08 & 1.10 & $<0.01$ \\
\hline
\end{tabular}

Az intervenciós program alkalmazása után a dobányzó serdülök dohányzási motivációi átrendezoódnek, a dohányzás ellen fordulnak.

Az intervenciós csoportban, a nemdohányzó serdülők esetében fennmarad a kontrollcsoportnál leírt tendencia, tehát a prevenció területén a program hatékonysága adataink dohányzó serdülők értékrendszere, dohányzási motivációi átrendeződnek, a dohányzás ellen fordulnak, teljesen ellenkező tendenciát mutatnak a dohányzó, de az intervencióban nem részesülő serdülők eredményeivel. 
Az intervenciós program alkalmazása után az. elszivivott cigaretták száma jelentösen csökkent a dobányzó serdülōk körében.

A fentiekben leírt eredményeket megerősítő vizsgálatokkal támasztottuk alá. Az intervenciós csoportot a dohányzás gyakorissága (havonta és naponta) és a dohányzási státusz (elszívott cigaretták száma) szerint elemeztük. A dohányzásra vonatkozó kérdések: (1) „Az elmúlt 30 napban hány napon cigarettázott?", (2) „Kérjük, gondolja át azokat a napokat, az elmúlt 30 nap során, amikor cigarettázott. Hány cigarettát sqivott el azokban a napokban?” és (3) „Az alábbi állitások közül melyik irja le a legjobban, hogy milyen gyakran cigarettázik??'. Az intervenció előtt és után adott válaszok közötti különbségek az elszívott cigaretták számát, a dohányzással jellemzett napok számát és az önjellemzett dohányzási státusz változásait mutatják.

A Wilcoxon előjeles rangszám próba különböző tendenciákat mutatott ki a dohányzás gyakoriságának mindhárom elemzett változója esetében. A magas mFTK értékú intervenciós csoportban esett a dohányzás gyakorisága, de a a különbség statisztikailag nem mérvadó. Például, a dohányzás havi gyakorisága tekintetében nem szignifikáns csökkenést tapasztaltunk - a medián poszt-tesztek rangjai $\mathrm{Mdn}=5$, az alaptesztelés rangjai pe$\operatorname{dig} \mathrm{Mdn}=4,5$ voltak. A magas mFTK értékű kontroll csoportban, statisztikailag jelentős növekedést mutattunk ki mindhárom dohányzási mutató esetében. Így, a három elemzett változó medián poszt-tesztjeinek rangjai $\operatorname{Mdn}=5, \operatorname{Mdn}=3, \operatorname{Mdn}=8$, az alap- tesztelés rangjai pedig $\operatorname{Mdn}=4, \operatorname{Mdn}=4$, $\operatorname{Mdn}=7$ voltak.

Az alacsony mFTK értékkel jellemzett intervenciós csoportban a havi cigarettázás gyakorisága szignifikánsan nőtt, ugyanígy a napi cigarettafogyasztás is jelentős mértékben emelkedett és az önjellemzett dohányzási státusz nagy mértékű dohányzásról számol be. $\mathrm{Az}$ alacsony mFTK értékkel jellemzett kontroll csoportban a cigarettázás gyakorisága (havi és napi gyakoriság, dohányzási státusz) jelentősen növekedett a két tesztelés közötti időszakban $(p<0.01, p<0.01, p<0.01)$.

\section{Megbeszélés}

Kutatásunkban az ASPIRA (Prokhorov és mtsai., 2010) számítógépes dohányzás prevenciós és intervenciós program magyar nyelvű verziójának (Nădăşan és mtsai., 2016) marosvásárhelyi alkalmazásából szerzett adatokat elemezzük, különös figyelemmel a dohányzási motivációk jellemzőire, valamint a program hatékonyságára. A program eredményességét a dohányzói viselkedés súlyosságának mértékével tettük összefüggésbe, a kis mértékben dohányzó-, valamint a szokássá rögzült dohányzó serdülők közötti összehasonlítások következtében. Cohen, Myers és Kelly (2002) szerint a nikotinfüggőség jelentôs tényezőt jelent a serdülők dohányzási kitartásában. Az mFTK eredményei szerint kimutatott függőség terminus serdülőknél való alkalmazásával szemben a szerzők óvatosságra intenek (Cohen, Myers és Kelly, 2002). Más szerzők vizsgálatai szerint az alkalmi do- 
hányosok idősebb korban kezdtek dohányozni, naponta kevesebb füstöt szívtak be, és szignifikánsan alacsonyabb értékeket értek el a függőségi skálán, de ugyanolyan nehézségekkel küzdöttek, mint a napi dohányzók, amikor megpróbálták abbahagyni a dohányzást (Rubinstein és mtsai., 2014). Kutatásunkban a dohányzás súlyosságát az mFTK kérdőívvel mértük, amely jelenleg a kutatások szerint a nikotinfüggóség olyan egyfaktoros mérőeszköze, amely elfogadható belső konzisztenciát és érvényességet mutat több országban való alkalmazás során (Prokhorov és mtsai., 2017). Eredményeink szerint a dohányzás súlyossági foka meghatározhatja, az intervenció lejárta után, a dohányzási motivációk eredményes szerveződését.

A serdülők dohányzási motivációinak mintázata eredményeink szerint különbözik a dohányzás súlyosságának, szokássá rögzülésének függvényében. Így, a dohányzó, nagyobb mFTK értékkel jellemzett serdülők több dohányzás mellett szóló érvet (Pros) sorakoztatnak fel, de ugyanakkor kevesebb dohányzás elleni motivációt (Cons) mutatnak. A teljes mintán, a kisebb mFTK értékeket elérô serdülők jelentősen nagyobb dohányzás elleni motiváció értékeket értek el az intervenció után, mint előtte. Ez a tendencia az egészséggel kapcsolatos ellenérvek, az esztétikai ellenérvek és az összesített dohányzás elleni motiváció tényezőt is végigkísérte.

Ha mintánkat az intervenciós, illetve kontroll csoporthoz tartozás szerint elemezzük, adataink kimutatják, hogy csoporthoz tartozástól függetlenül is, a keveset dohányzó fiatalok Dohányzás melletti értékei relatív stabi- lak, a Dohányzás elleni értékei viszont jelentősen csökkennek a legtöbb serdülő esetében. Egyes kutatások szerint a serdülőket korban előrehaladva, több olyan jellegzetes pszichés tényező befolyásolja, amelyek összefüggenek a dohányzási magatartással, mint például a szenzációkeresés, (Cservenka, 2013; Csibi és mtsai., 2015), vagy az önértékelés (Hale és mtsai., 2015; Sargent és mtsai., 2017).

Pénzes, Czeglédi, Balázs és Urbán (2017) kutatásai szerint a cigarettára rászokás, illetve leszokás folyamata magyar serdülők körében növekvő tendenciát mutat. Eredményeik alapján rámutattak, hogy a napi rendszerességű dohányzás gyakorisága a fiatalabb korosztályban több mint négyszeresére, az idősebb csoportban pedig közel kétszeresére növekedett a nagyobb mértékű emelkedést a lányoknál lehetett megfigyelni (Pénzes, Czeglédi, Balázs és Urbán, 2017).

Az intervenciós program szerintünk temperálja ezt a folyamatot és eléri, hogy a dohányzási magatartás a kezdeti szinten maradjon, ha nem is tudja ezt jelentősen csökkenteni.

$\mathrm{Az}$ intervenció teljes mértékben eredményes az intervenciós csoportban, a dohányzó, magas mFTK értékkel jellemzett serdülők esetében, ahol a dohányzási motivációk Dohányzás melletti értékei csökkennek (a Coping Pros jelentős mértékben), a Dohányzás elleni értékek pedig szignifikáns mértékben emelkednek. A kortársak befolyása jelentősen csökken, a belső, megküzdési motivációk felerősödnek, a serdülők pedig tudatosítani kezdik, feltehetőleg a program által nyújtott információk hatására, a dohányzás veszélyeit. 
A program hatékonyságát más mutatókkal is megvizsgáltuk, ezek a dohányzás gyakorisága (havonta és naponta) és a dohányzási státusz (elszívott cigaretták száma). Az alacsony mFTK értéket elért serdülőknél, a cigarettázás gyakorisága (havi és napi gyakoriság, dohányzási státusz) nőtt a két tesztelés között, de ez a viselkedésminta jellemző serdülőkre, ahol a kor elôrehaladtával jelentôsen emelkedik a dohányzási viselkedések száma (Pénzes, Czeglédi, Balázs és Urbán (2017).

A magas mFTK értékeket elért, kontroll csoportba tartozó serdülőknél mindhárom mutató szerint az elszívott cigaretták száma emelkedett. Az intervenciós csoportban fordított hatást észleltünk, tehát a dohányzás gyakoriságának mutatói statisztikailag szignifikáns csökkenést jeleztek. Adataink alapján mondhatjuk, hogy az ASPIRA program hatására, a már szokás szinten dohányzó serdülők cigarettafogyasztása jelentősen csökken, tehát a program sikeresen alkalmazható, intervenciós szinten, serdülő populáción.

Kutatásunk esetleges gyenge pontja, hogy mintánkat nem tekinthetjük országos szinten reprezentatívnak, a vizsgálat alatt pedig különböző okok miatt a serdülők egy része kilépett a vizsgálatból, ezért eredményeinket sem általánosíthatjuk a teljes serdülő populációra.

Erôs pont viszont, hogy a marosvásárhelyi középiskolák reprezentatív mintáján történt, és az intervenciós tevékenység az alaptesztelés és utótesztelés között, hat hónapos időintervallumot vett igénybe, megerôsítve adatainkat. Ugyanakkor, vizsgálatunk a prevenciós és intervenciós program hatásait követte a dohányzási viselkedés mélyebb struktúráira, valamint a dohányzási motivációk mintázatát tárta fel, kiemelve ezen programok alkalmazásának szükségességét.

\section{Következtetés}

A serdülők dohányzási magatartását, vizsgálatunkon belül a cigarettafogyasztását hatékonyan befolyásolhatjuk pozitív irányba, ha online, számítógépen (esetleg okostelefonon) elérhető prevenciós programokat alkalmazunk. Ezeknek a hatásmechanizmusa komplex, néha nehezen kimutatható, de pozitívan befolyásolja a serdülők dohányzással kapcsolatos attitűdjeit, motivációstruktúráit. Pénzes, Czeglédi, Balázs és Urbán (2017) kutatási adatai alátámasszák, hogy intervenció hiányában az általános iskolás korosztályban a rendszeres cigarettahasználat évről évre szinte megduplázódik. Guo és mtsai. (2009) szerint a dohányzók és nemdohányzók közötti különbségek elemzése bizonyítja, hogy a döntési egyensúly megváltoztatása viselkedésben bekövetkező változásokhoz vezet. Eredményeink szerint a külső, dohányzás melletti motivációk (mint például a szociális motiváció) mélyebb, belső dohányzás elleni érvekké alakulnak (például a dohányzás elleni, megküzdési motivációk) és elősegítik a cigarettafogyasztás visszaszorítását és akár a teljes abbahagyást.

\section{Összefoglalás}

A serdülőkori dohányzás a felnőttkori egészségi állapot egyik legjelentősebb kockázati magatartása. A prevenciós és leszokást tá- 
mogató programok hatékonyságának növelése céljából fontos a korai beavatkozás, valamint a serdülők szempontjából vonzó (például informatikai eszközökön is alapuló) módszerek alkalmazása.

Longitudinális kutatásunk prevenciós és leszokási beavatkozás elvégzése után jelentkező motiváció-átstrukturálódásokat elemez, valamint a számítógépes, iskolai beavatkozások hatékonyságát vizsgálja.

Módszer: az ASPIRA számítógépes dohányzás prevenciós és intervenciós program 6 hónapig tartó applikációja, valamint a program előtt és után kérdőívcsomag alkalmazása. A dohányzás gyakoriságát az elmúlt 30 napban és naponta az elszívott cigaretták számával mértük. A program hatékonyságának megvizsgálása céljából a résztvevőket két csoportra osztottuk a módosított Fagerström Tolerancia Kérdőív magas, illetve alacsony pontszámai alapján. A kérdőív tartalmazta a Döntési Egyensúly Skálát, amely a dohányzási motivációkat vizsgálja. Mintánk 16 marosvásárhelyi középiskola 16 osztályát, 1369, 1516 év közötti serdülőit tartalmazta.

Eredményeink szerint a dohányzó serdülők magasabb dohányzás melletti motiváció értékekkel és kevesebb dohányzás elleni érvekkel jellemezhetők a nem dohányzó serdülőkkel szemben. Az intervenciós program alkalmazása után a dohányzó serdülők dohányzás melletti motivációi csökkennek, míg a dohányzás hátrányaira fókuszáló motivációi szignifikáns mértékben emelkednek. Az intervenciós csoportban, a dohányzó serdülőknél esett a dohányzás napi és havi gyakorisága, a kontroll csoportban pedig statisztikailag jelentős növekedést észleltünk mindhárom dohányzási mutató esetében.

A program hatására az intervenciós csoportban, a magas mFTK értéket elért serdülőknél a dohányzási motivációk dohányzás melletti értékei csökkennek, a dohányzás elleni értékek pedig szignifikáns mértékben emelkednek. A dohányzó serdülők cigarettafogyasztása jelentősen csökken, így szerintünk az online számítógépes program sikeresen alkalmazható, intervenciós szinten, serdülő populáción.

\section{Irodalom}

Brick L. et al. (2017): Intervention effects on stage transitions for adolescent smoking and alcohol use acquisition. Psychology of addictive behaviors 31; 614. doi: 10.1037/adb0000302

Cohen, L.M., Myers, M.G. \& Kelly J.F. (2002): Assessment of nicotine dependence among substance abusing adolescent smokers: A comparison of the DSM-IV criteria and the modified Fagerström Tolerance Questionnaire. Journal of Psychopathology and Behavioral Assessment 24; 225-233. doi: 10.1023/A:1020722915204

Cservenka, A., Herting, M.M., Seghete, K.L., Hudson, K.A. \& Nagel, B.J. (2013): High and low sensation seeking adolescents show distinct patterns of brain activity during reward processing. Neuroimage 66; 184-193. doi: 10.1016/j.neuroimage.2012.11.003

Csibi M., Nădăşan V., Bálint I., Csibi S., Dénes M., Ábram Z. (2015): Differences in the sensation-seeking and depressive symptoms related to high school students' 
smoking status. Acta Medica Marisiensis 61, (Suppl 8); 17.

Denford S., Abrahan, Ch., Van Beurden, S., Smith, J. R. \& Morgan-Trimmer, S. (2017): Behaviour-change interventions for public health. In Tsekleves, E. \& Cooper, R. (eds.): Design for Health. London: Routledge. 58-71. doi: 10.4324/9781315576619-25

Guo, B., Aveyard, P., Fielding, A. \& Sutton, S. (2009): The Factor Structure and Factorial Invariance for the Decisional Balance Scale for Adolescent Smoking. Int J Behav Med. 16; 158-163. doi: 10.1007/s12529008-9021-5

Hale, W. J., Perrotte, J. K., Baumann, M. R. \& Garza, R. T. (2015): Low self-esteem and positive beliefs about smoking: A destructive combination for male college students. Addictive behaviors 46; 94-99. doi: 10.1016/j.addbeh.2015.03.007

Lindson-Hawley N., Thompson T.P. \& Begh R. (2015): Motivational interviewing for smoking cessation. [Online]. Accessed: 30th March 2018. Web: http://www.the healthwell.info/node/115326

Miech R., Schulenberg J., Johnston L., Bachman J., O'Malley P. \& Patrick M. (2017): Monitoring the Future National Adolescent Drug Trends in 2017: Findings Released. Ann Arbor, MI: Institute for Social Research, The University of Michigan. Accessed: March 30, 2018.Web: http://www.monitoringthefuture.org//pr essreleases/17drugpr.pdf

Nădăşan, V., Foley, K.L., Pénzes, M., Paulik, E., Mihăicuță, Ș., Ábrám, Z., Bálint, J., Csibi, M. \& Urbán R. (2016): The short- term effects of ASPIRA: a web-based, multimedia smoking prevention program for adolescents in Romania: a cluster randomized trial. Nicotine \& Tobacco Research 19; 908-915. doi: 10.1093/ntr/ntw308.

Pénzes M., Czeglédi E., Balázs P.és Urbán R. (2017): Dohányzói életutak magyar serdülók körében [Smoking trajectories among Hungarian adolescents]. Orv Hetil. 158; 67-76. doi: 10.1556/650.2017.30629

Pikó B. és Varga Sz. (2014): Mi motiválja a fiatalok dohányzását és alkoholfogyasztását? Magatartás-epidemiológiai elemzés [What motivates smoking and alcohol drinking of young people? A behavioural epidemiologic study]. Orv Hetil. 155; 100-105. doi: 10.1556/OH.2014.29805

Pikó B. (2008): Study of smoking behavior and smoking-related attitudes among preclinical medical students. Orv Hetil. 149; 2471-2478. doi: 10.1556/OH.2008.28516

Plummer, B.A., Velicer, W.F., Redding, C.A., Prochaska, J.O., Rossi, J.S., Pallonen, U.E. \& Meier, K.S. (2001): Stage of change, decisional balance, and temptations for smoking: Measurement and validation in a large, school-based population of adolescents. Addictive behaviors 26; 551-571.

Pócs D, Hamvai Cs and Kelemen O. (2017): Magatartás-változtatás az egészségügyben: a motivációs interjú. Orv Hetil. 158; 1331 1337. doi: 10.1556/650.2017.30825

Prokhorov, A.V., Kelder, S.H., Shegog, R., Conroy, J.L., Murray, N., Peters, R., Cinciripini, P.M., De Moor, C., Hudmon, K.S. \& Ford, K.H. (2010): Project ASPIRE: an Interactive, Multimedia Smoking 
Prevention and Cessation curriculum for culturally diverse high school students. Substance use \& misuse 45; 983-1006. doi: 10.3109/10826080903038050.

Prokhorov, A.V., Khalil, G. E., Foster, D. W., Marani, S.K., Guindani, M., Espada, J. P., Gonzálvez, M. T., Idrisov, B., Galimov, A., Arora, A., Tewari, A., Isralowitz, R., Lapvongwatana, P., Chansatitporn, N., Chen, X., Zheng, H. \& Sussman, S. (2017): Testing the nicotine dependence measure mFTQ for adolescent smokers: A multinational investigation. The American journal on addictions 26; 689-696. doi: 10.1111/ajad.12583

Prokhorov, A.V., Koehly, L. M., Pallonen U. E. \& Hudmon K. S. (1998): Adolescent Nicotine Dependence Measured by the Modified Fagerström Tolerance Questionnaire at Two Time Points. Journal of Child \& Adolescent Substance Abuse7; 35-47. doi: 10.1300/J029v07n04_0 $\underline{3}$

Rinfel, J., Oberling, J., Tóth, I., Prugberger, L. \& Nagy, L. (2011): Medical students' smoking habits and attitudes about cessation. Orvosi hetilap 152; 469-474. doi: 10.1556/OH.2011.29039

Rubinstein, M. L., Raita, M. L., Sen, S. \& Shiffman, S. (2014): Characteristics of adolescent intermittent and daily smokers. Addictive behaviors 39; 1337-1341. doi: 10.1016/j.addbeh.2014.04.021

Sargent, J. D., Gabrielli, J., Budney, A., Soneji, S. \& Wills, T. A. (2017): Adolescent smoking experimentation as a predic- tor of daily cigarette smoking. Drug \& Alcohol Dependence 175; 55-59. doi: 10.1016/j.drugalcdep.2017.01.038

Smith, R. F., McDonald, C. G., Bergstrom, H. C., Ehlinger, D. G., Brielmaier, J. M. (2015): Adolescent nicotine induces persisting changes in development of neural connectivity. Neurosci Biobehav Rev. 55; 432-443. doi: 10.1016/j.neubiorev.2015.05.019

U.S. Department of Health and Human Services 2014. The Health Consequences of Smoking - 50 Years of Progress: A Report of the Surgeon General. Atlanta: U.S. Department of Health and Human Services, Centers for Disease Control and Prevention, National Center for Chronic Disease Prevention and Health Promotion, Office on Smoking and Health. Aaccessed: 2018 march 30. Web: https://www.ncbi.nlm. nih.gov/ pubmed/24455788

Velicer, W. F., DiClemente, C. C., Prochaska, J. O. \& Brandenburg, N. (1985): Decisional balance measure for assessing and predicting smoking status. J Pers Soc Psychol 48; 1279-1289. doi: 10.1037//0022-3514.48.5.1279

WHO. Report on the global tobacco epidemic, 2017. Monitoring tobacco use and prevention policies. Geneva: World Health Organization. Licence: CC BY-NC-SA 3.0 IGO. 